\title{
Anticonvulsant activity of Shankhapuspi (Convolvulus pluricaulis Chois) on Strychnine induced seizure in experimental animals
}

\author{
Research article
}

\author{
Kshirod Kumar Ratha $^{1^{*}}$, Sthiti Srujani Mishra ${ }^{2}$ \\ 1. Research Officer (Ay.), Regional Research Institute of Himalayan flora, Tarikhet, \\ Ranikhet, Dist-Almora (U.K.) \\ 2. Ayurvedic Medical Officer, Govt. Ayurvedic College \& Hospita 1, Balangir, PO/ Dist- \\ Balangir (Odisha)
}

\begin{abstract}
The anticonvulsant activity of the aqueous extract of Convolvulus pluricaulis Chois (Shankhapuspi) was studied against Strychnine induced convulsions.

Seizure was induced by Strychnine in Shankhapuspi used animal model. The coadministration of the standard anticonvulsant drug Phenytoin sodium and aqueous extract of Shankhapuspi resulted in significant anticonvulsant activity when compared to the anticonvulsive activity of Phenytoin sodium.

The results of the study clearly suggested that Shankhapuspi can be prescribed as a co-therapeutic agent of Phenytoin for arresting seizures induced by Strychnine.

Keywords: Shankhapuspi, Covolvulus pluricaulis, Strychnine, Anticonvulsant activity.

\section{Introduction:}

Convulsive disorders are seen in 0.4 to 2 percent population in the world and that can occur at any age. (1) Recently it is one of the important subjects of concern especially for children and pregnant women. Being a global problem, the evaluation of patent and safe anticonvulsants is a matter of concern. The more recent studies show that the anticonvulsants used are hydantoins, valporate, barbiturates and benzodiazepines.(2) However due to their adverse effects like dependence, addiction, withdrawal symptoms and longer duration of treatment, the Ayurvedic products are

\footnotetext{
*Corresponding Author:

Kshirod Kumar Ratha

Research Officer (Ay.),

Regional Research Institute of Himalayan flora,

Tarikhet, Ranikhet, Dist-Almora (U.K.)

E-mail: drkkratha.ayu@ rediffmail.com
}

preferred now a days. Shankhapuspi (Convulvulus pluricaulis Chois) belongs to Convolvulaceae family and has been mentioned in Ayurveda, as a Rasayana which is mainly advocated for use on rejuvenation therapy. It is said to be the best among the medhya rasayana (intellectual promoting drug) (3) and is frequently indicated for the treatment of various mental diseases like epilepsy, insanity, obsession etc. Anticonvulsive, hypnotic, anxiolytic and mild analgesic actions of $C$. pluricaulis have been studied (4) and found that, extract of $C$. pluricaulis antagonizing the electrically induced convulsive seizures in rats and tremorine induced tremors in mice. Further antioxidant and anticonvulsant activity of methanolic extract of C.pluricaulis has shown to reduce the mean recovery time in maximal electricshock seizure model.(5,6)Though various evaluation of anticonvulsive activity works were done with Convolvulus pluricaulis $(7,8,9,10)$,
\end{abstract}


but use of its aqueous extract on strychnine induced seizure is done for the first time in the present work.

\section{Materials and Method:}

The study was carried out in the Department of Dravyaguna, Institute of Post Graduate Ayurvedic Education and Research, Kolkata and in the Department of Chemical Technology, University of Kolkata.

\section{Object:}

The main aim of the study was to evaluate the anticonvulsant activity of Shankhapuspi (Convolvulus pluricaulis Chois) on Strychnine induced convulsive seizures in animal models. This assay was used to evaluate the anticonvulsant activity of Sankhapuspi in convulsion, spasm of Tetanus etc. The interval of occurrence of tonic extensor convulsions and death following strychnine injection was noted. (11)

\section{Collection of Chemical and Material:}

The analytical grade of Strychnine Hydrochloride (S) and Phenytoin sodium (Epsolin) (12) was used for the present study were locally purchased.

\section{Collection of Plant Material:}

Whole part of the plant of Convolvulus pluricaulis was purchased from the local supplier and was authenticated by the institute as per usual norms.

\section{Preparation of Aqueous Extract:}

The fine powder of the herb Shankhapuspi was taken in a round bottle. Distilled water was added and extraction procedure was performed by decoction method for 48 hrs. After complete extraction, filtration method was adopted for getting clear extract solution. Filtrate clear extract solution was dried under rotary vacuum driers for complete removal of moisture and was placed in steam bath for few minutes.

\section{Dose Selection:}

Five random doses were selected for 6 separate groups of animals. The lowest dose was $100 \mathrm{mg} / \mathrm{kg}$ bw and the highest dose was $500 \mathrm{mg} / \mathrm{kg}$ bw. Drugs were measured accordingly and dissolved in distilled water. A stock was prepared and amount required for each rat was calculated.

\section{Selection of Standard Drug:}

Phenytoin sodium (epsolin) was choosen as standard drug for inhibiting seizures in the dose of $135 \mathrm{mg} / \mathrm{kg}$ bw, intraperitoneally. (13)

\section{Collection of Animals:}

Albino mice of either sex were collected and their weight varied between $20 \mathrm{gm}$ to $25 \mathrm{gm}$. They were maintained on standard laboratory diet and provided free access to water.

\section{Grouping of Animals:}

All the animals (mice) were divided into 9 groups each containing 5 in number. The groups of animal were kept in their respective cages marked on them. The 9 cages were marked with the sign. $\mathrm{C}$, $\mathrm{C}_{100}, \mathrm{C}_{200}, \mathrm{C}_{300}, \mathrm{C}_{400}, \mathrm{C}_{500}$, Strychnine, Phenytoin and Phenytoin $+\mathrm{C}_{400}$ to indicate control (normal saline), aqueous extract of Shankhapuspi in $100 \mathrm{mg}, 200 \mathrm{mg}, 300 \mathrm{mg}$, $400 \mathrm{mg}$ and $500 \mathrm{mg} / \mathrm{kg}$ bw, respectively. S indicates Strychnine Hcl (S) administrated in the dose of $2 \mathrm{mg} / \mathrm{kg} \quad \mathrm{bw}$, intraperitoneally. (14)

\section{Number of Experiments:}

5 sets of experiment were performed for evaluating anticonvulsant property of Convolvulus pluricaulis and the result obtained from the experiment were verified by various statistical analyses.

\section{Procedure of Drug Administration:}

The aqueous extract of Convolvulus pluricaulis was administered orally using feeding cannula of $2.5 \mathrm{~cm}$ 
long made up of Silver (AG) metal. It was introduced safely direct into the stomach. In this way the drug was administrated in accurate dose without useless mechanical loss. During administration, mice were carefully handled by which traumatic injury was avoided. Aqueous extract of Convolvulus pluricaulis was administered daily for 14 consecutive days.

\section{Experimental Procedure Strychnine Hcl (S) induced convulsion:}

Aqueous extract of $C$. pluricaulis was administrated to the experimental animal for 14 days prior to induction of convulsion in mice. Before 12 hours of induction of convulsion the food was withdrawn. In the morning the last dose of trial drug was administrated orally $1 \mathrm{hr}$ prior to induce convulsion with strychnine. Each mouse was placed in to an individual plastic cage for observation for $1 \mathrm{hr}$. The delay of onset was calculated in comparison with the control and standard groups.

\section{Observation:}

$\mathrm{ED}_{50}$ value was calculated. Further more, the time interval between Strychnine $\mathrm{Hcl}(\mathrm{S})$ injection and occurrence of seizure was measured. The delay onset was calculated in comparison with the control and standard groups.

Statistical Analysis:
The percentage changes due to effect of $C$. pluricaulis and Phenytoin sodium were calculated with respect to control. Various statistical analysis such as student' $t$ ' test, analysis of variance (ANOVA) and various multiple comparison analysis were performed to verify the level of significance.

\section{Results and Discussion:}

Different studies on Convolvulus pluricaulis were studied by the scholars from time to time. V.N. Sharma (1965) et al studied anti-convulsive effect of C.pluricaulis against electrically induced seizures, which showed the inhibitory effect of the drug. Present study showed significant anticonvulsant effect of the drug at the dosage of $400 \mathrm{mg} / \mathrm{kg}$ bw along with $135 \mathrm{mg} / \mathrm{kg}$ bw of Phenytoin sodium.

The results, verified by statistical analysis ( $t$-test and confidence level), are shown in appropriate tables. The analysis of variance (ANOVA) in two ways between the samples and between the animal sets and rank means have been shown.

The methods of evaluating anticonvulsive activity of Convolvulus pluricaulis in different doses along with Phenytoin are listed in Tab. -1 . The relative percent changes with respect to control along with statistical data have been listed in Tab. -1 and 2 \& Fig. 1 .

Table-1: Effect of Convolvulus pluricaulis $(\mathbf{C})$ on Strychnine (S) induced convulsion.

\begin{tabular}{|c|c|c|c|c|c|c|c|c|c|c|}
\hline \multirow{2}{*}{$\begin{array}{l}\text { Sampl } \\
\text { e }\end{array}$} & \multicolumn{2}{|l|}{ A1 } & \multicolumn{2}{|l|}{ A2 } & \multicolumn{2}{|l|}{ A3 } & \multicolumn{2}{|l|}{ A4 } & \multicolumn{2}{|l|}{ A5 } \\
\hline & $\begin{array}{l}\text { Average } \\
\text { onset of } \\
\text { convulsi } \\
\text { on } \\
\text { (minute) } \\
\pm \text { S.E. }\end{array}$ & $\begin{array}{l}\text { Relat } \\
\text { ive } \\
\text { perc } \\
\text { ent } \\
\text { chan } \\
\text { ge }\end{array}$ & $\begin{array}{l}\text { Average } \\
\text { onset of } \\
\text { convulsi } \\
\text { on } \\
\text { (minute) } \\
\pm \text { S.E. }\end{array}$ & $\begin{array}{l}\text { Relat } \\
\text { ive } \\
\text { perc } \\
\text { ent } \\
\text { chan } \\
\text { ge }\end{array}$ & $\begin{array}{l}\text { Average } \\
\text { onset of } \\
\text { convulsi } \\
\text { on } \\
\text { (minute) } \\
\pm \text { S.E. }\end{array}$ & $\begin{array}{l}\text { Relat } \\
\text { ive } \\
\text { perc } \\
\text { ent } \\
\text { chan } \\
\text { ge }\end{array}$ & $\begin{array}{l}\text { Average } \\
\text { onset of } \\
\text { convulsi } \\
\text { on } \\
\text { (minute) } \\
\pm \text { S.E. }\end{array}$ & $\begin{array}{l}\text { Relat } \\
\text { ive } \\
\text { perc } \\
\text { ent } \\
\text { chan } \\
\text { ge }\end{array}$ & $\begin{array}{l}\text { Average } \\
\text { onset of } \\
\text { convulsi } \\
\text { on } \\
\text { (minute) } \\
\pm \text { S.E. }\end{array}$ & $\begin{array}{l}\text { Relat } \\
\text { ive } \\
\text { perc } \\
\text { ent } \\
\text { chan } \\
\text { ge }\end{array}$ \\
\hline $\begin{array}{l}\text { Contro } \\
1\end{array}$ & $\begin{array}{ll}58.8 & \pm \\
0.80 & \end{array}$ & - & $\begin{array}{l}57.60 \pm 1 . \\
666\end{array}$ & - & $\begin{array}{l}57.6 \pm 1.6 \\
66\end{array}$ & - & $\begin{array}{l}56.8 \pm 1.0 \\
67\end{array}$ & - & $\begin{array}{l}58.2 \pm 0.9 \\
16\end{array}$ & - \\
\hline
\end{tabular}




\begin{tabular}{|l|l|l|l|l|l|l|l|l|l|l|}
\hline $\mathrm{C}_{100}$ & $\begin{array}{l}6.884 \pm 0 . \\
22\end{array}$ & $\begin{array}{l}88.1 \\
71^{\mathrm{a}}\end{array}$ & $\begin{array}{l}6.276 \pm 0 . \\
331\end{array}$ & $\begin{array}{l}89.1 \\
04_{\mathrm{a}}\end{array}$ & $\begin{array}{l}6.816 \pm 0 . \\
34\end{array}$ & $\begin{array}{l}89.2 \\
60^{\mathrm{a}}\end{array}$ & $\begin{array}{l}7.008 \pm 0 . \\
36\end{array}$ & $\begin{array}{l}87.6 \\
61^{\mathrm{a}}\end{array}$ & $\begin{array}{l}6.784 \pm 0 . \\
377\end{array}$ & $\begin{array}{l}88.3 \\
43^{\mathrm{a}}\end{array}$ \\
\hline $\mathrm{C}_{200}$ & $\begin{array}{l}7.848 \pm 0 . \\
376\end{array}$ & $\begin{array}{l}86.5 \\
15^{\mathrm{a}}\end{array}$ & $\begin{array}{l}7.156 \pm 0 . \\
349\end{array}$ & $\begin{array}{l}87.5 \\
76^{\mathrm{a}}\end{array}$ & $\begin{array}{l}8.04 \pm 0.3 \\
51\end{array}$ & $\begin{array}{l}86.0 \\
41^{\mathrm{a}}\end{array}$ & $\begin{array}{l}7.528 \pm 0 . \\
358\end{array}$ & $\begin{array}{l}86.7 \\
46^{\mathrm{a}}\end{array}$ & $\begin{array}{l}8.238 \pm 0 . \\
302\end{array}$ & $\begin{array}{l}85.8 \\
45^{\mathrm{a}}\end{array}$ \\
\hline $\mathrm{C}_{300}$ & $\begin{array}{l}9.896 \pm 0 . \\
576\end{array}$ & $\begin{array}{l}82.9 \\
96^{\mathrm{a}}\end{array}$ & $\begin{array}{l}9.056 \pm 0 . \\
813\end{array}$ & $\begin{array}{l}84.2 \\
77^{\mathrm{a}}\end{array}$ & $\begin{array}{l}9.12 \pm 0.3 \\
57\end{array}$ & $\begin{array}{l}84.1 \\
66^{\mathrm{a}}\end{array}$ & $\begin{array}{l}8.424 \pm 0 . \\
38\end{array}$ & $\begin{array}{l}85.1 \\
69^{\mathrm{a}}\end{array}$ & $\begin{array}{l}8.68 \pm 0.4 \\
07\end{array}$ & $\begin{array}{l}85.0 \\
85^{\mathrm{a}}\end{array}$ \\
\hline $\mathrm{C}_{400}$ & $\begin{array}{l}11.91 \pm 1 . \\
069\end{array}$ & $\begin{array}{l}79.5 \\
36^{\mathrm{a}}\end{array}$ & $\begin{array}{l}10.622 \pm \\
0.901\end{array}$ & $\begin{array}{l}81.5 \\
59^{\mathrm{a}}\end{array}$ & $\begin{array}{l}11.014 \pm \\
0.764\end{array}$ & $\begin{array}{l}80.8 \\
78^{\mathrm{a}}\end{array}$ & $\begin{array}{l}9.516 \pm 0 . \\
93\end{array}$ & $\begin{array}{l}83.2 \\
46^{\mathrm{a}}\end{array}$ & $\begin{array}{l}12.78 \pm 1 . \\
655\end{array}$ & $\begin{array}{l}78.0 \\
41^{\mathrm{a}}\end{array}$ \\
\hline $\begin{array}{l}\mathrm{C}_{500} \\
13.12 \pm 0 .\end{array}$ & $\begin{array}{l}77.4 \\
57^{\mathrm{a}}\end{array}$ & $\begin{array}{l}13.692 \pm \\
0.63\end{array}$ & $\begin{array}{l}76.2 \\
29^{\mathrm{a}}\end{array}$ & $\begin{array}{l}12.28 \pm 0 . \\
559\end{array}$ & $\begin{array}{l}78.6 \\
80^{\mathrm{a}}\end{array}$ & $\begin{array}{l}10.344 \pm \\
1.367\end{array}$ & $\begin{array}{l}81.7 \\
88^{\mathrm{a}}\end{array}$ & $\begin{array}{l}13.306 \pm \\
1.720\end{array}$ & $\begin{array}{l}77.1 \\
37^{\mathrm{a}}\end{array}$ \\
\hline $\begin{array}{l}\text { Strych } \\
\text { nine } \\
(\mathrm{S})\end{array}$ & $\begin{array}{l}1.876 \pm 0 . \\
152\end{array}$ & $\begin{array}{l}96.7 \\
76^{\mathrm{a}}\end{array}$ & $\begin{array}{l}2.162 \pm 0 . \\
30\end{array}$ & $\begin{array}{l}96.2 \\
46^{\mathrm{a}}\end{array}$ & $\begin{array}{l}2.028 \pm 0 . \\
295\end{array}$ & $\begin{array}{l}96.4 \\
79^{\mathrm{a}}\end{array}$ & $\begin{array}{l}2.58 \pm 0.3 \\
4\end{array}$ & $\begin{array}{l}95.4 \\
57^{\mathrm{a}}\end{array}$ & $\begin{array}{l}2.148 \pm 0 . \\
294\end{array}$ & $\begin{array}{l}96.3 \\
09^{\mathrm{a}}\end{array}$ \\
\hline $\begin{array}{l}\text { Phenyt } \\
\text { oin }\end{array}$ & $\begin{array}{l}50.984 \pm \\
1.822\end{array}$ & 12.3 & $\begin{array}{l}49.796 \pm \\
98^{\mathrm{a}}\end{array}$ & $\begin{array}{l}1.54 \\
8^{\mathrm{a}}\end{array}$ & $\begin{array}{l}47.758 \pm \\
2.791\end{array}$ & $\begin{array}{l}17.0 \\
86^{\mathrm{b}}\end{array}$ & $\begin{array}{l}47.616 \pm \\
1.858\end{array}$ & $\begin{array}{l}16.1 \\
69^{\mathrm{b}}\end{array}$ & $\begin{array}{l}49.426 \pm \\
1.741\end{array}$ & $\begin{array}{l}15.0 \\
75^{\mathrm{b}}\end{array}$ \\
\hline $\begin{array}{l}\text { Phenyt } \\
\text { oin } \\
\mathrm{C}_{400}\end{array}$ & $\begin{array}{l}56.316 \pm \\
1.395\end{array}$ & 3.23 & $\begin{array}{l}54.8 \pm 1.0 \\
7^{\mathrm{d}}\end{array}$ & $\begin{array}{l}4.86 \\
19\end{array}$ & $\begin{array}{l}50.102 \pm \\
2.750\end{array}$ & $\begin{array}{l}13.0 \\
17^{\mathrm{b}}\end{array}$ & $\begin{array}{l}53.146 \pm \\
1.466\end{array}$ & $\begin{array}{l}6.43 \\
3^{\mathrm{c}}\end{array}$ & $\begin{array}{l}54.012 \pm \\
1.761\end{array}$ & $\begin{array}{l}7.19 \\
5^{\mathrm{c}}\end{array}$ \\
\hline
\end{tabular}

A1-A5 indicate experimental sets

$\neq$ Average (minute) of five observations

S.E. $=$ Standard error $(n=5)$

$\mathrm{C}_{100}, \mathrm{C}_{200}, \mathrm{C}_{300}, \mathrm{C}_{400}$ and $\mathrm{C}_{500}$ indicate C.pluricaulis in the doses of $100 \mathrm{mg}, 200 \mathrm{mg}, 300 \mathrm{mg}$, $400 \mathrm{mg}$ and $500 \mathrm{mg}$ per kg body wt. respectively. Control indicates administration of normal saline. Phenytoin administered as standard drug in the dose of $135 \mathrm{mg}$ per $\mathrm{kg}$ I.P.

Reproducibility values are measured by ' $\mathrm{t}$ ' test and the values are significant at ${ }^{\mathrm{a}} p<0.01$; ${ }^{\mathrm{b}} p>0.1$.

Table-2: Statistical analysis of variance (ANOVA) and multiple comparision analysis of C.pluricaulis of different doses on Strychnine (S) induced convulsion.

\begin{tabular}{|c|c|c|c|}
\hline \multirow{2}{*}{$\begin{array}{l}\text { ANOVA } \\
\text { (Two ways) }\end{array}$} & \multicolumn{3}{|c|}{ Multiple comparisons } \\
\hline & $\begin{array}{l}\text { Least significant } \\
\text { different } \\
\text { procedure }\end{array}$ & $\begin{array}{l}\text { Student zed range } \\
\text { procedure }\end{array}$ & $\begin{array}{l}\text { Duncan's } \\
\text { multiple } \\
\text { procedure }\end{array}$ \\
\hline $\begin{array}{l}\mathrm{F}_{1}=6411.189^{\mathrm{a}} \\
(\mathrm{df}=7,28) \\
\mathrm{F}_{2}=1.383^{\mathrm{b}} \\
(\mathrm{df}=4,28)\end{array}$ & $\begin{array}{l}\text { Critical } \\
\text { difference }=1.4491 \\
\left(\mathrm{C}_{100}\right)\left(\mathrm{C}_{200}\right) \\
\left(\mathrm{C}_{300}\right)\left(\mathrm{C}_{400}\right)\left(\mathrm{C}_{500}\right) \\
\text { (Phenytoin) } \\
\left.\text { (Phenytoin }+\mathrm{C}_{400}\right)\end{array}$ & $\begin{array}{l}\text { Critical } \\
\text { difference }=3.9195 \\
\left(\mathrm{C}_{100}\right)\left(\mathrm{C}_{200}\right) \\
\left(\mathrm{C}_{300}\right)\left(\mathrm{C}_{400}\right)\left(\mathrm{C}_{500}\right) \\
\text { (Phenytoin) } \\
\left.\text { (Phenytoin+C } \mathrm{C}_{400}\right)\end{array}$ & $\begin{array}{l}\text { Critical } \\
\text { difference }=3.0538 \\
\left(\mathrm{C}_{100}\right)\left(\mathrm{C}_{200}\right) \\
\left(\mathrm{C}_{300}\right)\left(\mathrm{C}_{400}\right)\left(\mathrm{C}_{500}\right) \\
\text { (Phenytoin) } \\
\left.\text { (Phenytoin }+\mathrm{C}_{400}\right)\end{array}$ \\
\hline
\end{tabular}


$\mathrm{C}_{100}, \mathrm{C}_{200}, \mathrm{C}_{300}, \mathrm{C}_{400}$ and $\mathrm{C}_{500}$ indicate C.pluricaulis in the doses of $100 \mathrm{mg}, 200 \mathrm{mg}$, $300 \mathrm{mg}$, 400mg and 500mg per kg body wt. respectively. Phenytoin administered as standard drug in the dose of $135 \mathrm{mg}$ per $\mathrm{kg}$ I.P.

$F_{1}$ and $F_{2}$ indicate analysis between samples and between animal sets respectively Significance levels of $\mathrm{F}$ values: ${ }^{\mathrm{a}} p<0.001 ;{ }^{\mathrm{b}} p<0.10$

$\neq \neq$ Two means not included in the same parenthesis are statistically significantly different at $p<0.05$.

\section{Figure 1: Relative percentage changes of C.pluricaulis activity on Strychnine (S) induced Convulsion.}

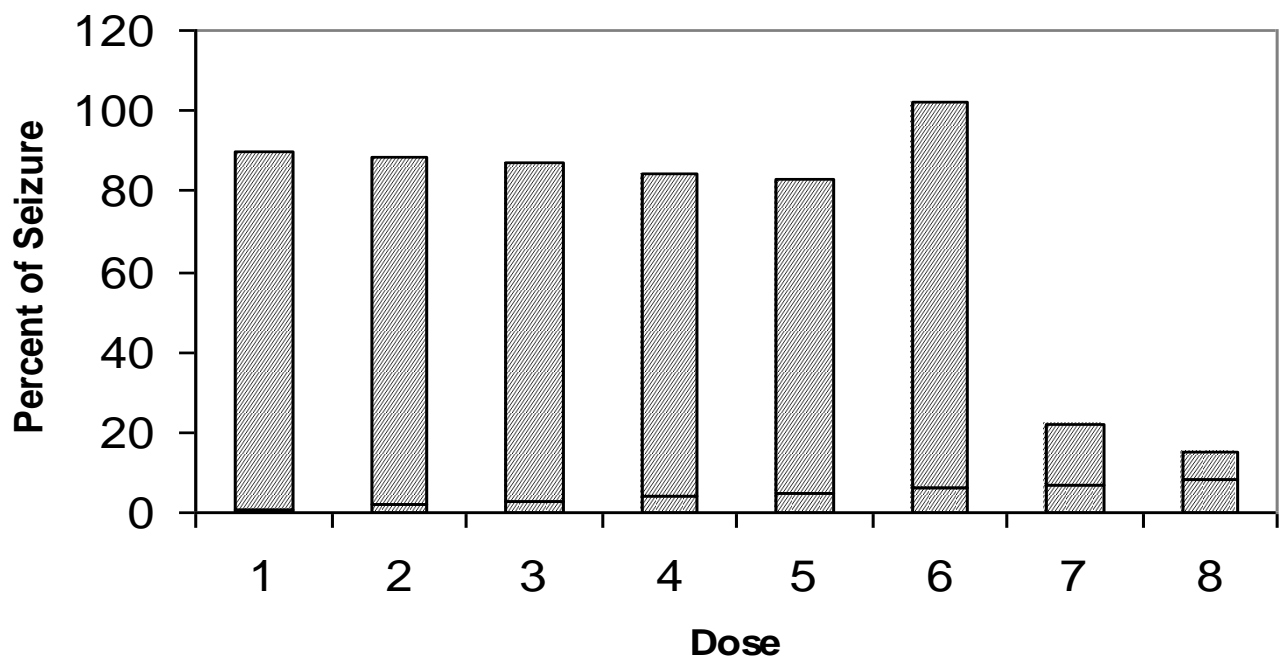

' $1-5$ ' indicate C.pluricaulis in the doses of 100-500 mg/ $\mathrm{kg}$ bodyweight respectively, ' 6 ' indicates Strychnine administered in the dose of $2 \mathrm{mg} / \mathrm{kg}$ bodyweight , ' 7 ' indicates Phenytoin sodium administered in the dose of 135 $\mathrm{mg} / \mathrm{kg}$ bodyweight and ' 8 ' indicates Phenytoin administered along with C.pluricaulis in the doses of $400 \mathrm{mg} / \mathrm{kg}$ bodyweight.

From the observations it appeared that Convolvulus pluricaulis in the dosage of $(100-500 \mathrm{mg} / \mathrm{kg})$ has no significant inhibition effect on Strychnine induced convulsion, however Convolvulus pluricaulis in the dose of $400 \mathrm{mg} / \mathrm{kg}$ bw is administrated in combination with Phenytoin sodium (135 mg/kg bw) showed significant inhibitory effect on Strychnine induced convulsion. Thus the therapeutic index of Phenytoin sodium is enhanced by increasing $\mathrm{LD}_{50}$ value without altering $\mathrm{ED}_{50}$ value.

\section{Conclusion}

It can be concluded that only the aqueous extract of Shankhapuspi (Convolvulus pluricaulis) $(500 \mathrm{mg} / \mathrm{kg} \mathrm{bw})$ could not arrest seizure induced by Strychnine where as aqueous extract of Convolvulus pluricaulis in the dosage of $400 \mathrm{mg} / \mathrm{kg}$ bw acted as co-therapeutic agent of Phenytoin sodium for arresting seizure induced by Strychnine $\mathrm{Hcl}$ (S).

\section{Acknowledgement}

The author is thankful to Dr. P.K.Mukherjee, Project Director, Dr.B.P.Shaw, Reader, Kayachikitsa of IPGAE\&R, Kolkota and Dr.Achintya saha, Reader, Dept.of chemical technology, University of Calcutta for providing 
facilities of technical assistance, valuable guidance and support.

\section{References}

1. Ditcher M.A, Fauli A, et al. Harrisons Principle of Internal Medicine. $14^{\text {th }}$ ed. New York; MC Graw Hill Companies; 1997. 1968p.

2. Tripathy K.D. Essential of Medical Pharmacology. $4^{\text {th }}$ ed. Delhi; Jaypee Publication; 2000. 387-388p.

3. Shastri S.N. Charak Samhita (Chikitsa sthanam). $\quad 2^{\text {nd }} \quad$ ed. Varanasi; Chowkhamba Vidyabhavan;1970.39p

4. Sharma K, Arora V, Rana A.C., Bhatnagar M. Anxiolytic effect of Convolvulus pluricaulis Choisy petals on elevated plus maze model of anxiety in mice. $\mathrm{J}$ Herb Med Toxicol.2009; 3 (1); 41-46p.

5. Sharma VN, Barar FSK, Khanna NK, Mahawar MM. Some pharmacological actions of Convolvulus pluricaulis: an Indian indigenous herb. Ind $\mathbf{J}$ Med Res.1965; 53 (9);871-76p

6. Pawar S.A., Dhuley J.N.,Naik S.R. Pharm Biol.2001;39(4); 253-58p

7. Verma S, Sinha R, Kumar P, Amin F, Jain J, Tanwar S.Study of Convolvulus pluricaulis for
Antioxidant and Anticonvulsant Activity. 2012;12(1);55p

8. Panda S, Kar A. Inhibition of $\mathrm{T} 3$ production inlevothyroxine-treated female mice by the root extract of Convolvulus pluricaulis. Horm Metab Res.2001; 33(1); 16-18p.

9. Mudgal V. Studies on medicinal properties of Convolvulus pluricaulis and Boerhaavia diffusa. Planta Med.1975; 28(1);62-68p

10. Barar FSK, Sharma VN. Preliminary pharmacological studies on Convolvulus pluricaulis Chois: an Indian indigenous herb. Ind J Physiol Pharmacol.1966; 9(2);99-102p

11. Vogel H.G, Vogel W.H. Drug Discovery and Evaluation. Berlin; Springer; $1997.260 \mathrm{p}$

12. Goodman and Gillman. Principle of Pharmacological basis of therapeutics.10 ${ }^{\text {th }}$ ed. New York; Mc Graw Hill; 2001.468p

13. Ghosh M.N.Fundamental of experimental pharmacology. Calcutta; Oxford and IBH Publishing Co;1984.199p

14. Vogel H.G, Vogel W.H. Drug Discovery and Evaluation. Berlin; Springer; $1997.228 p$ 